\title{
Relationship of Family Experience with the Acceptance of Family Members Who Have Mental Disorders
}

\author{
Aszrul AB ${ }^{1}$, Fatmawati ${ }^{*}$, Fitria Syam ${ }^{3}$ \\ Departemen Community and Family Nursing , Stikes Panrita Husada Bulukumba, Indonesia ${ }^{1}$ \\ Departemen Mental Health Nursing, Stikes Panrita Husada Bulukumba ,Indonesia ${ }^{2}$ \\ S1 Nursing Study Program, Stikes Panrita Husada Bulukumba, Indonesia ${ }^{3}$
}

Corresponding Autor : $\underline{\text { nengfatma@gmail.com * }}$

\begin{abstract}
Mental disorders are disorders that affect one or more functions of the soul that are characterized by disruption of emotions, thought processes, behaviors, and perceptions (sensory capture). This mental disorder causes stress and suffering for sufferers and their families. The family is the closest unit to a family member who has a mental disorder and is the "Main Nurse" for the client. The family plays a role in determining the way or nursing care required by the client. This study aims to determine the relationship of family experience with family acceptance of family members who have mental disorders. The design of this study is qualitative, using a cross-sectional approach. The sample selection in this study was carried out using the Slovin formula so that 52 respondents were identified. The instrument used was a questionnaire. The results of this study indicate that the results obtained value of $\mathrm{P}=0.01$ where the value of $\mathrm{P}<0.05$ and $\mathrm{r}=0.827$, it means that there is a strong relationship or correlation between family acceptance with family experience of families with mental disorders in Ujung Loe Health Center Bulukumba Regency. The relationship between family acceptance and family experience can be seen that family experience of families with mental disorders in Ujung Loe Health Center, Bulukumba District is known from the level of family experience that shows 6 families have a good experience, 46 families have a poor experience and none of the respondents in the good category. While the level of family acceptance is $3(6 \%)$, the level of acceptance is good, 49 families the level of acceptance is quite good. The results of this study can be concluded that good family acceptance is closely related to the formation of family experiences on mental disorders. The results of this study also indicate that the higher the family experience, the greater the self-acceptance that will form in the client.
\end{abstract}

Keywords: Family experience, Family Acceptance, Mental disorders

\section{INTRODUCTION}

According to the World Health Organization Report (WHO, 2010) about the Global Burden Disease said, now there has been a change in the type of disease that creates a burden for the country globally. Previously, WHO said that the case of maternal and child mortality was the biggest burden for the country, but now it is shifting to chronic diseases, including severe mental illness, for example, mental disorders. In Indonesia itself, severe mental illness is also quite high. Based on Basic Health Research (Riskesdas 2013) the prevalence of severe mental disorders in the Indonesian population is 1.7 per 


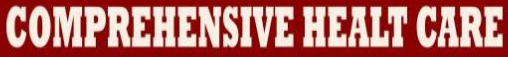

mile. Most severe mental disorders in Yogyakarta, Aceh, South Sulawesi, Bali, and Central Java. The proportion of RTs who had already had ART with severe mental illness was 14.3 percent and the majority was in the population living in rural areas (18.2\%), as well as in the population group with the lowest ownership index quintile (19.5\%). The prevalence of mental-emotional disorders in Indonesia's population is 6.0 percent. Provinces with the highest prevalence of mental disorders are Central Sulawesi, South Sulawesi, West Java, In Yogyakarta, and East Nusa Tenggara.

Professor of Public Health, University of Indonesia, Ascobat Gani calculated minimal economic losses due to mental health problems based on Riskades 2010 and 2007 amounting to $\mathrm{Rp} 20$ trillion. He delivered the data in the MDGs and Mental Health seminar in 2010. He said, the highest number of inpatient jamkesmas patients in hospitals (RS) Class A in 2010 were Hebephrenic Undifferentiated Schizophrenia (1,924 people) Paranoid Schizophrenia (1,612 people), Undifferentiated Schizophrenia (4430 persons), Schizophrenia Unspecified (400 people) Paranoid Schizophrenia (1,612 people), Undifferentiated Schizophrenia (443 0 persons), Schizophrenia Unspecified (400 people) Schizophrenia (399 people). That number does not include outpatients. Of the total risk population of $1,093,150$, only 3.5 percent or 38,260 have only been served in psychiatric hospitals, public hospitals or community health centers with adequate facilities.

According to Agus Utomo (2012) Founder of the Home of the Indonesian Schizophrenic Suffering Community (KPSI) that the handling or recovery process of patients with mental disorders, one of which is Schizophrenia in Indonesia is still bad. He explained, the process of handling People with Schizophrenia (ODS) was long. Starting from treatment in hospitals, administering drugs, to social support; family and community. Even though a patient has gotten the medicine well, the recovery process in the hospital is going well, but if the family and the environment are not supported at home, then the patient's disease will recur. Government data shows that in Indonesia there are 18 thousand ODS installed. Generally, people with mental disorders are depressed because they can cause unrest which makes families anxious and can disturb the peace and tranquility of others. Besides, many families who send their family members who are ODS to mental hospitals, clinics, mental health treatment foundations, bring to shamans, boarding schools for mad people, or social shelter. In fact, after 


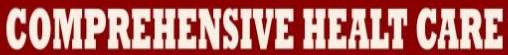

returning from the hospital or other place of treatment, they (ODS) also need a place for social rehabilitation, a gathering place, and others.

According to Andrea Star Reese (2012), one of the Time magazine reporters in one of her visits to Indonesia for a year from January 2011 to 2012 covering treatment sites for people with mental illnesses said that a common obstacle for Indonesian people was choosing to confine their family members because of problems of access to care; high medical costs and lack of basic information dissemination. Andreas also mentioned the lack of psychiatrists in Indonesia. He cited government data which showed that Indonesia had around 600 - 800 psychiatrists, half based on Java, half of them on Java, of which 50 percent were in Jakarta.

According to Emil Agustiono (2010), Deputy for the Coordination of Health, Population and Family Planning, the Coordinating Ministry for People's Welfare said in the Public Awareness campaign 'Lighting the Hope for Schizophrenia that the public should not underestimate mental health issues because it includes long-term illness that reduces nation's productivity. He continued that the disease could pose a significant burden to the country and must be resolved across sectors and with collaborative efforts to overcome these mental health problems by raising public awareness to participate in increasing the productivity of sufferers with appropriate support. The family is the closest unit to the client and is the "Main Nurse" for the client. The family plays a role in determining the way or nursing care needed by clients at home. The success of a nurse in a hospital can be in vain if it is not continued at home which then results in the client having to be treated again (relapse). Family participation since the beginning of care at the hospital will increase the ability of the family to take care of clients at home so that the possibility can be prevented (Yosep, 2007).

The results of the study by Wulansih and Widodo (2008) regarding the relationship between family attitudes and recurrence in schizophrenic patients showed that the number of respondents who had a bad attitude with patients who treated $>3$ times there were 6 people (12\%). The number of respondents who have a good attitude with patients who do care 2 times there are 19 people (38\%) and who do care $>3$ times there are 25 people (50\%). This shows that the better the attitude of the family will further reduce the recurrence of schizophrenic patients. Several other studies related to this research will be about the phenomenological study of family experiences about the burden and source of family support in caring for family members with hallucinations in 
the Cimahi and Bandung areas identifying eight research themes namely psychological burden, financial burden, problems in health services, social support, family support, unconditional attention, disappointment in the providers of support and destiny. This study for psychiatric nursing recommends that nurses will further enhance competence in conducting assessments of family needs in caring for clients with hallucinations so that it will be more appropriate in intervening to families especially to improve abilities and minimize the burden felt by the family (Ng presence, 2011).

Based on data from the field, in the Ujung Loe sub-district area, people with mental disorders were found on the streets and they did not get a decent life even though they were mentally disturbed. The best place for mental patients should be at home because the family's role is crucial to the patient's recovery. Preliminary data results are based on interviews of 5 family members who were dropping off and visiting family members in Ujung Loe Puskesmas, Bulukumba Regency, 3 states people who do not like and do not want to care for family members who experience mental disorders. The perception of mental disorders is an embarrassing disease, a disgrace, and a frightening specter. Not even a few who send family members to a mental hospital because they are ashamed of the negative assumptions of neighbors about family members who have mental disorders. Based on the description above, the authors are interested in conducting research with the title "the relationship of family experience with the acceptance of family members who have mental disorders in Ujung Loe Health Center, Bulukumba district.

\section{MATERIAL AND METHODS}

This study uses a quantitative method with a descriptive survey research design that aims to make an assessment of the implementation of a program in the present and then the results to formulate plans for program improvement in the future. CrossSectional study is used to study the dynamics of the correlation between risk factors and effects, by way of approach, observation or data collection. The design of this study was used to find out the relationship of family experience to the acceptance of family members who have mental disorders in the Ujung Loe Health Center, Bulukumba Regency.

The population is the overall object to be studied (Sukardi, 2010). The population in this study is the family members of patients with mental disorders in Ujung Loe Health Center in 2016 as many as 60 people. The sample in this study were 52 people, The 
instrument in this study used a questionnaire containing questions, the respondent only had to answer Always (Sl), Often (Sr), Rarely (Jr), Never (Tp). The questions and statements given are validated theoretically and empirically. Empirical validation is a field trial instrument given to a number of respondents as a sample that has the same characteristics as the population to be measured. Respondents' answers are then analyzed to determine whether they are valid or invalid.

Bivariate analysis using Pearson Correlation or often called Product Moment Correlation (KPM) is a statistical test tool used to test the associative hypothesis (relationship test) of two variables if the data is interval or ratio scale. In this study, the independent variable is a family experience while the dependent variable is the acceptance of family members towards families with mental disorders (Y). data processing techniques submitted through questionnaire sheets using an alternative choice between one to five with the provisions of the answers always weighting score 4; answers often score 3; answers rarely score weights 2; answers never score weights 1 .

\section{RESULTS}

Table 1. Distribution of Respondents by Gender, age, education level

\begin{tabular}{lcc}
\hline Gender & $\mathbf{n}$ & Percentage (\%) \\
\hline Female & 24 & 46.2 \\
Male & 28 & 53.8 \\
Age & & \\
10-20 Tahun & 10 & 19.2 \\
21 - 35 Tahun & 26 & 30,8 \\
36 - 60 Tahun & 26 & 50.0 \\
Level Of Education & & \\
Basic & 10 & 19.2 \\
Middle & 25 & 48.1 \\
High & 15 & 28.8 \\
Bachelor & 2 & 3.8 \\
\hline Amount & $\mathbf{5 2}$ & $\mathbf{1 0 0 . 0}$ \\
\hline
\end{tabular}

Based on table 1 above, it is known that the gender distribution of respondents in the study of family experiences and their relationship with the acceptance of family members experiencing mental disorders in Ujung Loe Health Center, Bulukumba Regency, out of 52 respondents there were 24 respondents (46.2\%) who were female and 28 respondents ( 53.8\%) are male. Most respondents of family members who experience mental disorders and do examinations in the Ujung Loe Puskesmas unit in Bulukumba Regency out of 52 respondents are known to be 10 respondents $(19.2 \%)$ 
aged $<20$ years, 16 respondents (30.8\%) aged $21-35$ years and 26 respondents (50\%). Most respondents of family members who experience mental disorders and conduct examinations in the Ujung Loe Puskesmas unit in Bulukumba Regency out of 52 respondents are known to be 10 respondents (19.2\%) having an elementary education level, 25 Respondents (48.1\%) have a junior high school / MTs, 15 respondents (28.8\%) have high school / MA education levels and 2 respondents (3.8\%) have tertiary education levels.

Table 2. Distribution of Family Experience and Family Acceptance of Family Members with Mental Disorders.

\begin{tabular}{lcc}
\hline Chategory & n & Percentage (\%) \\
\hline Good & 46 & $88,4 \%$ \\
Pretty good & 6 & $2,6 \%$ \\
Not good & 0 & $0 \%$ \\
Chategory & & $6 \%$ \\
Good & 3 & $94 \%$ \\
Pretty good & 49 & $0 \%$ \\
Not good & 0 & $\mathbf{1 0 0 . 0}$ \\
\hline Amount & $\mathbf{5 2}$ & \\
\hline
\end{tabular}

From table 2 it is known that family experiences in providing health care to family members who have mental disorders are still in the good category. It is known from 52 respondents who were the object of research there are 6 families that have good experience, 46 families have poor experience and none of the respondents are in the poor category. Family acceptance of family members who experience mental disorders are still in the good category. It is known from 52 respondents who were the object of research there are 3 (6\%) families whose level of acceptance is good, 49 families the level of acceptance is quite good and none of the respondents describe that they do not accept families with mental disorders.

Tabel 3. Correlation test of family experience with family experience of family members

\begin{tabular}{|c|c|c|c|c|c|c|c|}
\hline \multirow{3}{*}{ Family Experience } & \multicolumn{4}{|c|}{ Family Acceptance } & \multirow[t]{3}{*}{$\mathrm{n}$} & \multirow[t]{3}{*}{$\%$} & \multirow[t]{3}{*}{$P$ value } \\
\hline & \multicolumn{2}{|c|}{ Good } & \multicolumn{2}{|c|}{ Not Good } & & & \\
\hline & $\mathrm{n}$ & $\%$ & $\mathrm{n}$ & $\%$ & & & \\
\hline Good & 3 & 5,8 & 3 & 5,8 & 6 & 88,4 & 0,01 \\
\hline Not Good & 5 & 9,6 & 41 & 78,8 & 460 & 11,6 & \\
\hline Amount & 8 & 15,3 & 44 & 84,6 & 52 & 100 & \\
\hline
\end{tabular}

Correlation test of family experience with family experience of family members who have mental disorders in Ujung Loe Puskesmas, Bulukumba district, obtained statistical test results that show a probability value ( $p$ value) $>$ alpha 0.05 results of family acceptance $P$ value $=0.01$ or rcount value $=0.827$ so that it can be concluded that there 
is a correlation between family acceptance with family experience of families with mental disorders in Ujung Loe Health Center, Bulukumba Regency.

\section{DISCUSSION}

The results of this study indicate that family experiences in providing health care to family members who have mental disorders are still in the good category. It is known from 52 respondents who were the object of research there are 6 families that have a good experience, 46 families have a poor experience and none of the respondents are in the poor category. Friedman (2013) states that the family is seen as a system. Then the interference that occurs in one family member can affect the entire family system. A good experience can give a positive influence on the condition in which a person when exposed to an illness then he can directly or indirectly occur two things. Directly experience can make someone behave healthily, and not panic when exposed to an illness indirectly the experience received from others can reduce tension so it does not cause interference (Kaplan, 2007).

Forms of experience such as support and attention given by the family to clients can be in the form of caring for clients with patience and by always showing a pleasant attitude when serving clients. The attention given will cause peace of mind and a sense of comfort for the client. So things like this will motivate the client to live his life. Kuntjoro (2012), states that this type of emotional support will enable a person to get emotional attachment (closeness) so as to create a sense of security for those who receive. This kind of support can be obtained from a spouse or close family member and has a harmonious relationship. For clients with mental disorders, this support can be provided by family members who live in the same house with the client so that the support provided can be received directly by the client. In this study, the results obtained that the emotional support received by the client is good. This can be seen from the client's family members who take the client is the client's closest family, that is, a family member who lives in the same house with the client.

This shows that emotional support in this study can be received directly by the client. Family experience in providing instrumental/financial support that is the family is responsible for client expenses related to daily needs and expenses for health care. Care in the Outpatient Unit is one of the instrumental support provided by the family to clients. Based on the results of interviews with respondents, most respondents said that in terms of economic function, the family still could not provide optimally. This can be 
seen by researchers when conducting research that most of the families who deliver make a visit to Ujung Loe Puskesmas, Bulukumba Regency, they earn less.

Form of informational support according to Taylor family involves providing information, advice or feedback about individual situations and conditions, this type of information will help individuals to identify and resolve problems more easily. For clients with mental disorders with environmental conditions like this, the client will feel more valued and cared for by the surrounding environment, so that it will help in the formation of the Family experience towards In this study adequate informational support was received by most clients because some of the client families had a high school / equivalent education.

The level of education that is good enough for the family identifies that the family has quite good knowledge. This is in line with the results of Asmika, Chuluq and Sutrisnani's (2012) research, which states that the level of education determines the intellectual condition of a person to think critically in making decisions before acting or choosing something before doing it.

Rahmadani (2010), also states that someone who is educated will better understand the exact needs of caring for his family. Providing appreciation for clients with mental disorders will help clients in their recovery because by giving this award support clients will feel they are still needed in the family. This is in line with the statement of Subekti (2015), that the family has a role as reinforcement or reinforcement that can be realized by giving praise or gifts when the client shows success in taking action. The results of this study indicate family acceptance of family members who experience mental disorders is still in the good category. It is known from 52 respondents who were the object of research there are 3 (6\%) families whose level of acceptance is good, 49 families the level of acceptance is quite good and none of the respondents describe that they do not accept families with mental disorders. The strong family experience of patients with mental disorders in this study is due to past illness experiences which are one of the causes of not forming good self-esteem in clients, this makes families look only in negative terms. Feelings of lack of confidence in the family make it difficult for them to return to socializing with the community and tend to shut down.

This is in line with the opinion expressed by Kline in Supriyanti (2007), that someone who has low self-esteem and negative views such as feeling helpless has a high risk of becoming depressed. They are always dominated by negative evaluations of 
themselves, the environment and the future. Disorders of low self-esteem are described as negative feelings towards oneself including loss of self-confidence and self-esteem, feeling like they have failed to achieve their desires. Correlation test of family experience with family experience of family members who experience mental disorders in Ujung Loe Puskesmas, Bulukumba district, obtained statistical test results that show a probability value ( $p$-value) $>$ alpha 0.05 results of family acceptance $P=0.01$ value or recount value $=0.827$ so that it can be concluded that there is a correlation between family acceptance with family experience of families with mental disorders in Ujung Loe Health Center, Bulukumba RegencyFrom the results of this study, it can be concluded that good family acceptance is closely related to the formation of family experiences of mental disorders. The results of this study also indicate that the higher the family experience, the greater the self-acceptance that will form in the client.

\section{CONCLUSIONS}

Statistical test results that indicate the probability value ( $p$ value) $>$ alpha 0.05 results of family acceptance $\mathrm{P}$ value $=0.01$ or rcount value $=0.827$ so that it can be concluded that there is a correlation between family acceptance with family experience of families with mental disorders At Ujung Loe Health Center, Bulukumba Regency .The client's family at Ujung Loe Health Center in Bulukumba Regency is expected to be able to increase the support to the client so that there is no decrease in self-esteem to the client so that there is no recurrence of the client.

\section{REFERENCES}

Alfiatin, T. (2010). Yogayakarta: Gadjah mada university press.

Dahlan, M. (2010). Besar sampel dan cara pengambilan sampel. Jakarta: Salemba Medika.

Dalami, E., Suliswati, Rochimah, Suryati, k. r., \& Lestari, w. (2014). Asuhan keperawatan klien dengan gangguan jiwa. Jakarta timur: CV.Trans info media.

Dharma, K. K. (2015). Metodologi Penelitian Keperawatan. Jakarta: CV. Trans Info Media. eko, p. (2014). keperawatan jiwa. nuha medika.

Harvina, s. (2015). faktor lingkungan tempat tinggal yang berhubungan dengan berhenti pakai narkoba suntik. jurnal kedokteran dan kesehatan malikussaleh .

Imam, d. (2014). tinjaun hukum pidana terhadap tindak pidana penyalagunaan narkotika (studi kasus dipengadilan negeri surakarta). tinjauan hukum pidana terhadap tindak pidana penyalahgunaan narkotika yang dilakukan oleh anggota TNI, jurnal serambi hukum . 
Indrawati, d. (2014). profil keluarga disfungsional pada penyandang masalah sosial di kota semarang. jurnal psikologi undip .

Jannah, R., \& Fajria, r. (2016). Analisis tingkat kecanduan akibat penggunaan narkotika dan obat-obatan terlarang dengan metode fuzzy logic. Teknik informatika fakultas ilmu komputer universitas almuslim .

Lisa, J., \& Sutrisna W, N. (2013). Narkoba psikotropika dan gangguan jiwa tinjauan kesehatan dan hukum. Yogyakarta: Nuha Medika.

Mekar, A. d. (2013). metode kualitatif dalam bidang kesehatan. muha medika.

Muhammad, a. b., \& Sari, a. f. (2016). Studi kualitatif motivasi pecandu narkoba dalam tahap rehabilitasi untuk berhenti menggunakan narkoba di balai rehabilitasi rsj sambang lihum banjarmasin. Studi kualitatif motivasi pecandu narkoba.

Prabowo, e. (2014). Buku ajar keperawatan jiwa. Yogyakarta: Nuha medika.

Prasanti ditha, K. e. (2017). preservasi kearifan lokal, dalam komunikasi teraupeutik bagi keluarga perkotaan. studi kasus tentang obat keluarga sebagai presevasi kearifan lokal dalam komunikasi terauputik bagi keluarga perkotaan .

Purnomowardani dewanti agnes, K. (2000). penyingkapan diri, perilaku seksual, dan penyalahgunaan narkoba. jurnal psikologi .

Rahardjo, w. (2010). Konsumsi alkohol, obat-obatan terlarang dan perilaku seks beresiko: suatu studi meta-analisis. Jurnal psikologi .

Ramadona, E., \& Agustin, H. (2014). Faktor yang berhubungan dengan penyalahgunaan narkoba di RSJ Prof.HB Saanin. Jurnal kesehatan masyarakat andalas .

Rusdi, D. D. (2013). konsep dan kerangka kerja asuhan keperawatan jiwa. Yogyakarta: Gosyen Publishing.

Saleh, H. D., Rokhmana, D., \& Nafikandini. (2014).

Saryono. (2010). metode penelitian kualitatif dalam bidang kesehatan. muha medika.

Saryono, A. d. (2013). metodologi penelitian kualitatif dalam bidang kesehatan. muha medika.

SRI, W. N. (2015). HUB.. JURNAL.

Suyanto. (2011). Metodologi dan aplikasi penelitian keperawatan. Yogyakarta: Nuha Medika.

Thariqul, M. c. (2014). Terapi indah dan pecandu. jurnal al-murrabi .

Tito, S. S. (2016). analisis penyebab remaja mengkomsumsi narkoba ditinjau dari kesalahan pendidikan keluarga di pontianak. program studi pendidikan sosiologi . 